Ivana Brač

\title{
INSTRUMENTAL U KOPULATIVNIM REČENICAMA
}

dr. sc. Ivana Brač, Institut za hrvatski jezik i jezikoslovlje, ibrac@ihjj.hr, Zagreb

izvorni znanstveni članak

UDK 81 '366.548

$81 ' 367.3$

rukopis primljen: 13. 3. 2017.; prihvaćen za tisak: 13. 5. 2017.

U radu je ukratko prikazano shvaćanje strukture kopulativnih rečenica u svjetskom jezikoslovlju te problematizirana podjela na predikatne, specifikacijske, ekvivalentne $i$ identifikacijske rečenice. Naglasak je na predikatnim kopulativnim rečenicama u kojima se u hrvatskom jeziku, kao i u pojedinim slavenskim jezicima, imenska skupina poslije kopule može ostvariti nominativom ili instrumentalom. Istražit će se ograničenja povezana s tom pojavom. Također će se na temelju primjera iz korpusa analizirati može li se na hrvatski jezik primijeniti pretpostavka iznesena za ruski jezik da se instrumentalom izražava privremeno svojstvo, dok nominativom trajno. Utvrdit će se osjećaju li izvorni govornici tu razliku na temelju ankete u kojoj je sudjelovalo 106 ispitanika.

Ključne riječi: kopula; kopulativne rečenice; instrumental; nominativ; hrvatski jezik; ruski jezik

\section{Određivanje kopule i strukture kopulativnih rečenica u svjetskom jezikoslovlju}

Poznato je da glagol biti ima više različitih upotreba ili značenja. Uz pomoćni glagol biti, koji se upotrebljava za tvorbu pojedinih glagolskih oblika, razlikuju se egzistencijalni i neegzistencijalni glagol biti. Egzistencijalni glagol biti javlja se u egzistencijalnim (Do revolucije su u Moskvi bili konjski tramvaji.), lokativnim (Novci su bili na stolu.) i posesivnim konstrukcijama (U Tanje su bili novci. 'Tanja je imala novaca.'), dok se neegzistencijalni glagol biti, odnosno kopula javlja u predikatnim (Maye su bile vješti astronomi.) i ekvivalentnim konstrukcijama (Zvijezda Danica je Venera.) ${ }^{1}$ (usp. Pereltsvaig 2007). Egzistencijalni glagol biti punoznačni je glagol koji se može zamijeniti određenim sinonimima, npr. postojati, boraviti, nalaziti se, imati i sl., dok je neegzistencijalni glagol biti kopula, odnosno semantički je prazan (usp. Silić i Pranjković 2005: 289-290).

1 O tome treba li razlikovati egzistencijalne i lokativne rečenice v. u Birtić 2001 i Zovko Dinković 2011. 
Budući da je kopula funkcionalna kategorija bez značenja koja povezuje subjekt $\mathrm{s}$ neglagolskim predikatom (v. Radford 2004: 445), potreban je leksički dio predikata kako bi rečenica imala značenje, a u toj se ulozi mogu javiti imenica (On je bio učitelj.), pridjev (On je bio dobar.), imenska skupina u genitivu (On je niska rasta.), kao-skupina (On je kao njegov otac.) i dr. U tim je rečenicama kopula nužna da bi navedene kategorije mogle imati funkciju predikata. Te se rečenice nazivaju kopulativnim rečenicama, a njihova je struktura temeljito opisana u svjetskoj literaturi. Higgins (1973) napravio je taksonomiju kopulativnih rečenica $u$ engleskom jeziku na temelju referencijskoga ${ }^{2}$ svojstva imenske skupine ispred i iza kopule, te tako razlikuje četiri vrste rečenica':

1. predikatne (predicational) Bill is a scuba diver. 'Bill je ronilac.'

2. specifikacijske (specificational) The person I like most is my father. 'Osoba koju najviše volim je moj otac.'

3. ekvivalentne (identity (equative)) The Morning Star is the Evening Star. 'Jutarnja zvijezda je Večernja zvijezda.', That man is Bill. 'Taj čovjek je Bill.'

4. identifikacijske (identificational) That animal is a tiger. 'Ta životinja je tigar.', That is Joe Smith. 'To je Joe Smith.'

Higgins (1973) objašnjava da je u predikatnim kopulativnim rečenicama ${ }^{4}$ imenska skupina prije kopule referencijska, a poslije kopule jest predikat koji opisuje svojstvo subjekta. Specifikacijske rečenice ne pripisuju svojstvo referentu, nego se određuje točno tko ili što odgovara opisu ispred kopule. Ta rečenica nije ni o subjektu ni o predikatu, stoga nijedan nije referencijski, tj. subjekt ograničuje domenu, a specifikacijski predikat identificira određenoga člana te domene (v. Higgins 1973: 198). Ekvivalentne rečenice imaju dva referencijska izraza koji se odnose na istoga referenta, a u rečenici se izjednačuju. Identifikacijske rečenice, slično kao i predikatne, imaju referencijski subjekt koji je označen kakvom deiksom (pokazne ili lične zamjenice), a predikat identifikacijski, npr. vlastito ime, a služe za učenje imena ljudi i stvari.

Ubrzo se postavilo pitanje je li zaista riječ o četirima različitim vrstama kopulativnih rečenica. Rapoport (1987) zaključuje da su identifikacijske i specifikacijske rečenice vrsta ili predikatne ili ekvivalentne, što su prihvatili mnogi jezikoslovci. Najviše je pozornosti posvećeno specifikacijskim rečenicama za koje mnogi smatraju da su zapravo predikatne kopulativne rečenice u inverziji (npr. Williams 1983, Partee 1986, Heggie

2 U gramatici se pod pojmom referencijalnosti podrazumijeva određeni entitet izvanjezičnoga svijeta u određenom kontekstu koji je poznat slušatelju (v. Rapaport 1987: 29, Radford 2004: 474). Higgins (1973: 204) upotrebljava naziv referencijski za pokazne i lične zamjenice, vlastita imena i determinatorske skupine (DP).

3 U radu se ne drži njegova redoslijeda te su nazivi na engleskom napisani malim slovom za razliku od originala.

4 U ovom se članku pod predikatnom rečenicom ne misli na vrstu zavisnosložene rečenice, nego na rečenicu koja ima strukturu XP KOPULA YP, s tim da je XP referencijska imenska skupina, a YP imenska ili pridjevska skupina. Kako bi se izbjegla moguća zabuna, upotrebljavat će se naziv predikatna kopulativna rečenica. 
1988, Moro 1997, Mikkelsen 2005). ${ }^{5}$ Naime, mnogi autori, krenuvši od Stowella (1978: 465-466), smatraju da je kopula glagol s podizanjem koji ima dopunu malu surečenicu. Subjekt male surečenice podiže se i postaje subjekt glavne rečenice, odnosno nalazi se s lijeve strane kopule. Tako nastaju predikatne rečenice $s$ kanonskim redoslijedom riječi. Heggie (1988: 66) smatra da su specifikacijske rečenice nastale derivacijom iz predikatne strukture tako da je topikalizirana predikatna dopuna nakon pomicanja subjekta. ${ }^{6}$ Subjekt male surečenice pomiče se na mjesto SpecIP, a u specifikacijskim rečenicama predikatna imenska skupina pomiče se na mjesto SpecCP (v. Mikkelsen 2005: 8). ${ }^{7}$ Više o specifikacijskim rečenicama v. Williams 1983, Heggie 1988, Moro 1997, Mikkelsen 2005, den Dikken 2006, Heycock 2012 i dr.

Time se dolazi do predikatne i ekvivalentne rečenice kao dviju vrsta kopulativnih rečenica koje se razlikuju po tome što se u predikatnim kopulativnim rečenicama svojstvo izraženo poslije kopule pripisuje referencijskomu subjektu ispred kopule, dok u ekvivalentnim rečenicama skupina poslije kopule ne pripisuje svojstvo referencijskomu subjektu, nego označuje točno određeni entitet u svijetu, odnosno izjednačuje subjekt $s$ imenskim dijelom predikata (v. Rapaport 1987: 28). Rapoport (1987), Mikkelsen (2005) i dr. smatraju da je u tim rečenicama riječ o različitim glagolima. ${ }^{8}$ No postoje i pristupi koji smatraju da je riječ o jednom glagolu biti (npr. Heggie 1988).

Pretpostavku o postojanju dviju različitih leksičkih jedinica koje odgovaraju kopuli prihvatila je Pereltsvaig (2007), koja time objašnjava pojavu nominativa i instrumentala

5 Postoje i drukčija mišljenja. Naime, Heycock i Kroch 1999, Rothstein 2001 i dr. smatraju da specifikacijske rečenice nisu povezane s predikatnim kopulativnim rečenicama, nego su podvrsta ekvivalentnih, dok den Dikken (2006) smatra da su ekvivalentne vrsta specifikacijskih rečenica.

6 Belaj i Tanacković Faletar (2017: 144-145), u okviru kognitivne gramatike, navode da postoje dva tipa binominativnih konstrukcija, odnosno konstrukcija s dvjema imenskim skupinama u nominativu, koje se razlikuju prema svojemu obavijesnom ustrojstvu. Tako rečenicu Ubojica je mjesni liječnik. određuju kao konstrukciju identifikacijskoga tipa u kojoj se „utvrđuje identitet neodređenoga, ali specifičnoga predstavnika kakve kategorije” i služi „imenovanju pojedinačnoga predstavnike kakve šire kategorije u specifičnom komunikacijskom kontekstu". U tom je primjeru mjesni liječnik dio nove obavijesti, dok je u rečenici Mjesni liječnik je ubojica., koju određuju kao konstrukciju kategorizacijskoga tipa koja nije usko ograničena na jedan komunikacijski kontekst, mjesni liječnik poznata obavijest.

7 Važno je napomenuti da je u hrvatskom jeziku podizanje subjekta male surečenice na mjesto subjekta glavne rečenice ograničeno na vrlo malen broj glagola. Točnije, činiti se (1), ispasti (2), ispadati, pokazati se (3), te na glagole izgledati, djelovati i sl. u tom značenju.

(1a) Čini se da je ona luda.

(1b) Ona se čini ludom/luda.

(2a) Ispalo je da je Budiša naivac.

(2b) Budiša je ispao naivcem/naivac.

(3a) Pokazalo se da je utakmica nezanimljiva.

(3b) Utakmica se pokazala nezanimljivom/?nezanimljiva.

Belaj i Tanacković Faletar (2017: 145-153) upozoravaju na to da za određivanje statusa subjekta u binominativnim konstrukcijama identifikacijskoga tipa testovi podizanja subjekta male surečenice na mjesto subjekta odnosno objekta glavne rečenice nisu pouzdani. O ograničenjima u vezi s tim preoblikama v. i Kučanda 1998.

8 Stowell (1989: 255) razlikuje predikatni biti koji je glagol s podizanjem i identificirajući glagol biti koji je dvomjesni predikat koji uspostavlja odnos identifikacije između dviju referencijskih imenskih skupina, odnosno argumenata. 
u kopulativnim rečenicama u ruskom jeziku. Smatra da je u rečenicama s dvostrukim nominativom kopula funkcionalna kategorija koja ne dodjeljuje padež i semantičke uloge, nego između subjekta (DP) i imenskoga predikata (DP) dolazi do koindeksiranja na razini sintakse i do koreferencije na razini semantike, a koja za posljedicu ima istinitost rečenice ako su DP prije kopule i poslije kopule identični. U rečenicama $s$ imenskom skupinom u instrumentalu (NP) kopula je leksička kategorija, odnosno kopulu smatra „lakim” glagolom (light verb) koji dodjeljuje leksički padež svojim dopunama.

Pereltsvaig (2007) objašnjava da se DP može pojaviti samo nominativno obilježen te se zbog toga u ekvivalentnim rečenicama ne javlja instrumental, dok se u predikatnim kopulativnim rečenicama javlja NP ili AP u nominativu ili instrumentalu.

U ovom ćemo se radu baviti rečenicama u kojima je skupina ispred kopule referencijska, a iza kopule nalazi se nereferencijska imenska ili pridjevska skupina (NP ili AP). Drugim riječima, predikatnim kopulativnim rečenicama $s$ kanonskim redoslijedom riječi. Poznato je da se u tim rečenicama u pojedinim slavenskim jezicima mogu javiti nominativ ili instrumental u predikatnom dijelu, a ta je pojava najbolje istražena $u$ ruskom jeziku, čemu će se posvetiti pozornost u sljedećem poglavlju.

\section{Instrumental u predikatnim kopulativnim rečenicama u ruskom i drugim slavenskim jezicima}

U literaturi o ruskom jeziku (Jakobson 1936: 80, Mrázek 1964: 214, Wierzbicka 1980: 119, Janda i Clancy 2002: 36, Timberlake 2004: 287, Geist 2006, Pereltsvaig 2007: 94ff) obično se smatra da je nominativom obilježeno trajno, neotuđivo, inherentno svojstvo (4), a instrumentalom prolazno, epizodično, stečeno (5).

\section{(4) Иван был солдат. Ivan je bio vojnik. \\ (5) Иван был солдатом. \\ Ivan je bio vojnikom.}

Prema tumačenju A. Wierzbicke (1980: 120) rečenica (4) znači da je Ivan cijeli život bio vojnik, a u rečenici (5) on je promijenio profesiju. Potebnja (1888/1954: 504) navodi da se nominativom identificira osoba u cjelini, dok se instrumentalom navodi što je ona uz mnoge druge stvari, odnosno riječ je o odnosu dio i cjelina, kako navodi Geist (2006). Geist (2006: 106) uvodi i treće tumačenje koje temelji na pragmatici, točnije smatra da će se instrumental upotrijebiti kada se opisuje nestvarna, imaginarna situacija ili kada govornik želi ograničiti svoju tvrdnju na određenu situaciju, a nominativ za opis stvarne situacije ili kada je govornikov odnos prema situaciji neutralan.

Takav se zaključak može naći i u opisu drugih slavenskih jezika u kojima je moguća alternacija nominativa i instrumentala. U vezi s ukrajinskim Shevelov (1993: 980) navodi da je izbor između nominativa i instrumentala slobodan, no instrumental je češći, osim uz prezent kada se upotrebljava nominativ. 
U poljskom postoji morfološko ograničenje da se imenske skupine javljaju u instrumentalu (Jan jest studentem. 'Jan je studentom.'), dok se pridjevske javljaju isključivo u nominativu (Jan jest golodny. 'Jan je gladan.'), bez obzira na glagolsko vrijeme. Swan (2002) navodi da se imenska skupina može javiti u nominativu samo uz konstrukcije to jest, odnosno to je: Ten pan to (jest) moj znajomy. 'Taj čovjek je moj poznanik.' i u uvredama Jestes kompletny idiota / kompletnym idiota. 'Ti si potpuni idiot/ potpunim idiotom'. Pridjev u službi predikatnoga imena može se javiti u instrumentalu uz glagole činiti se i postati, što Swan (2002: 364) smatra obilježjem starije književnosti. Također pridjev može biti u instrumentalu ako je glagol biti dio složenoga predikata: Trzeba być odważnym. 'Treba biti hrabrim.', uz glagolsku imenicu bycie i gerund będąc, odnosno glagolski prilog sadašnji i prošli. Češki i slovački jezik nemaju takvo ograničenje. U vezi s češkim Short (1993a) i Ribarova i Ribarova (2015) navode da često ne postoji jasna granica u upotrebi nominativa i instrumentala, no navode da instrumental ima privremeno značenje uz imenice koje znače zanimanje ili funkciju te osobinu (Naš novy soused je bankarem/banker. 'Naš novi susjed je bankarom/bankar.'), dok nominativ izriče stalnu osobinu (Tamta žena je moje sestra/Francouzka. 'Ta žena je moja sestra/ Francuskinja.'). Short (1993a: 500) navodi da u inverziji instrumental postaje obvezan (Jedinou zárukou úspěchu je rozumné zacházení s penězi. 'Jedinim jamstvom uspjeha je razumno raspolaganje novcem.') te u nestvarnim pogodbenim rečenicama (Kdybych byl tvým otcem. 'Kad bih bio tvojim ocem.'). Za slovački Short (1993b: 571) navodi da se nominativ upotrebljava za stalna ili općenita svojstva (byt' Slovák), a instrumental „is strongly preferred in more concrete, topical, relativized contexts" i stoga označuje zanimanja, titule i funkcije, rodbinske odnose i sl. (byt svedkom/dcérou "biti svjedokom/ kćeri'). U vezi s lužičkosrpskim Short (1993c) navodi da predikatno ime dolazi u nominativu, a u instrumentalu se može javiti samo s prijedlogom $z$ (Jan je z wučerjom. 'Jan je učitelj.'). No katkad se javlja instrumental, što Short (1993c: 659) smatra knjiškom pojavom i vjerojatno utjecajem drugih slavenskih jezika u kojima njegova upotreba češća i čvršća.

Za starocrkvenoslavenski jezik Huntley (1993: 164) i Damjanović (2005: 171) navode da je predikatno ime u nominativu, a iznimno $u$ instrumentalu, $i$ to kada označuje „anomalous temporary change of state”, objašnjava Huntley (1993: 167). U slovenskom je jeziku predikatno ime uvijek u nominativu, a instrumental se ne javlja čak ni uz semikopulativne glagole (v. Priestly 1993). Rijetka pojava instrumentala u srpskom jeziku određena je obilježenom, odnosno javlja se „izuzetno u poetskom tekstu kao, pre svega, stilska odlika jezika tek ponekog pisca" (Piper i dr. 2005: 239). U bosanskom jeziku Jahić, Halilović i Palić (2004: 366) navode da se može javiti instrumental uz glagol u prošlom vremenu, ali je uvijek zamjenjiv nominativom te navode samo primjere kada je predikatno ime imenica. Iz toga se da zaključiti da ta pojava nije uobičajena u južnoslavenskim jezicima, no pokušat će se utvrditi u kojim slučajevima do nje uopće dolazi. 


\subsection{Razvoj instrumentala u kopulativnim rečenicama}

Zanimljivo je da su istraživanja pokazala da je pojava instrumentala u kopulativnim rečenicama novija pojava u ruskom jeziku (Mrázek 1964, Bailyn i Rubin 1991).

Mrázek (1964) smatra da se ta pojava širila sa slavenskoga sjevera na jug i u različitom opsegu zahvatila slavenske jezike. Smatra da je u početku instrumental nosio adverbijalno značenje, odnosno njime se opisuje kako se subjekt vratio, u kojoj je funkciji išao kamo, kakav je oblik dobio, na koje su ga mjesto postavili i sl., a da bi se u jeziku izbjegla dvosmislenost u takvim rečenicama, instrumental je zamijenio nominativ. Instrumental je odabran iz semantičkih razloga, odnosno povezuje ga sa značenjem načina djelovanja, ali i sa značenjem sredstva uz glagole imenovanja. Mrázek (1964: 214) smatra da se instrumental prvo pojavio u rečenicama koje su izražavale imenovanje, dužnosti, funkcije. Zatim se počeo upotrebljavati uz glagole koji izražavaju kakvu promjenu, primjerice претвориться 'pretvoriti se', сделать (ся) кем-чет 'učiniti (se) kime-čime', стать 'postati', zatim uz оказаться 'pokazati se', представляться 'predstavljati se' i dr. te na kraju uz glagol бblmb 'biti', i to u prošlim vremenima, participima, a kasnije i uz infinitiv te se povezivao s prolaznošću. Prvo su instrumentalom bile zahvaćene imenice, a dosta kasnije pridjevi. U početku je bio čisto semantički padež s konkretnim značenjem, a kasnije se desemantizirao, odnosno dobio svoju sintaktičku funkciju. Tako je prošao put od padeža koji se javljao uz punoznačne glagole do pojavljivanja uz glagol koji je čista veza.

Bailyn i Rubin (1991: 114) i Bailyn (1991: 76) navode da u staroruskom i starocrkvenoslavenskom te mnogim suvremenim slavenskim jezicima, među kojima je i hrvatski, dolazi do udvostručivanja padeža u sekundarnim predikatima dodatcima, odnosno prošircima (Marina je našla Sašu pijan(og)a., Mi smo plesali goli.) te u rečenicama s kopulom. Zaključili su da je u suvremenom ruskom jeziku uvedeno dodatno pravilo kojim se izbjegava udvostručivanje padeža tako da se nominativ zamjenjuje instrumentalom (Марина нашла Сашу пьянылм. 'Marina je našla Sašu pijanim.'). Na pitanje zašto se baš instrumental pojavio u tim strukturama, Bailyn i Rubin (1991: 117-118) navode dva moguća odgovora: 1. analogijom prema malim surečenicama dodatcima u kojima se javljaju prava sredstva $u$ instrumentalu te subjektnomu instrumentalu; 2. analogijom prema glagolima казаться, cчumamb, odnosno činiti se i smatrati. Vjerojatnijim smatraju prvi razlog.

\subsection{Pojava instrumentala $u$ kopulativnim rečenicama $u$ hrvatskom jeziku}

Prema gore navedenim tumačenjima hrvatski se smatra jezikom koji čuva starije stanje, stoga je potrebno utvrditi kada se instrumental počeo javljati u hrvatskom i pod kojim utjecajem. U radu ćemo se osvrnuti samo na pretisnute starije gramatike u kojima se piše o glagolu biti i instrumentalu. No da bi se dobili pouzdani rezultati, treba proučiti korpus djela starije hrvatske književnosti, što nadilazi temu ovoga rada. Kašić (1604) navodi da glagol opstojnosti zahtijeva i ispred i iza sebe nominativ, ne spomenuvši instrumental kao mogućnost. Della Bella (1728) ne bilježi upotrebu instrumentala uz kopulativni glagol biti, dok Babukić (1854: 360) navodi da je uz glagole biti, bivati te 
postati, nazivati, imenovati običniji instrumental od nominativa, no opisujući glagole kojima treba instrumental, ne navodi glagol biti. Weber (1859: 16-17) navodi da je predikatno ime uz glagol biti u nominativu, no u poglavlju o instrumentalu Weber (1859: 44) piše da instrumental dolazi s glagolima biti, postati, imenovati itd. Kao što je rečeno, da bi se sa sigurnošću moglo tvrditi kada se počeo upotrebljavati instrumental na predikatnom imenu i u kojim tekstovima, nužno je proučiti djela starije hrvatske književnosti. Pregledom navedenih gramatika čini se da se to dogodilo u 19. stoljeću, no pitanje je je li riječ o propustu pri opisu ili te pojave zaista nije bilo ranije. Rišner (2002) analizirala je primjere s predikatnim imenom $u$ instrumentalu uz glagol biti u prvom redu u književnim i znanstvenim tekstovima i zaključila da upotreba instrumentala ovisi o piščevu stilu te da u drugoj polovici devetnaestoga i početkom dvadesetoga stoljeća upotreba instrumentala nije bila stilski obilježena. Silić i Pranjković (2005: 235) navode da se od posljednjega desetljeća 20. stoljeća učestalije koristi instrumentalom, a razlog je taj što se instrumental uz glagol biti smatra specifičnošću hrvatskoga jezika naspram srpskoga, no i dalje ostaje pitanje zašto se pojavio u 19. stoljeću i koliko je bila česta ta pojava.

\section{Instrumental u predikatnim kopulativnim rečenicama u suvremenom hrvatskom jeziku}

U suvremenim hrvatskim priručnicima instrumental uz glagol biti obično se smatra stilski obilježenim u odnosu na nominativ (Barić i dr. 1997, Silić i Pranjković 2005, Raguž 2010, Belaj i Tanacković Faletar 2014), odnosno obilježjem biranoga stila (Marković 2009). U gramatikama se često navode ograničenja glagolskoga vremena, tako Barić i dr. (1997: 402) navode da se instrumental može javiti u prošlom vremenu, a „u sadašnjem i budućem vremenu samo s naglašenim oblicima pomoćnih glagola” (6) ili „ako je predikat proširen priložnom oznakom” (7).

(6) Ja jesam skrbnikom. Ja hoću biti skrbnikom.

(7) Odsada sam vam ja skrbnikom. Odsada ću vam ja biti skrbnikom.

Upotrebu instrumentala uz nenaglašeni glagol biti u prezentu i futuru Barić i dr. (1997) smatraju izrazito stilski obilježenom u odnosu na perfekt. Rišner (2002: 10, fn. 3) u vezi s tim naglašava kako te rečenice imaju različito obavijesno ustrojstvo, pa se u rečenici s nenaglašenim oblikom ističe predikatno ime u instrumentalu, a u rečenici s naglašenim oblikom ističe se „jesnost pomoćnoga glagola”.

Silić i Pranjković (2005: 290) navode da se instrumental rijetko javlja uz prošla vremena, a uz prezent i futur smatraju ga obilježenim. Marković (2009: 232) upotrebu predikatne imenice u instrumentalu u prošlom ili budućem vremenu, rijetko u prezentu, označuje odlikom „biranijega, svečanijega pisanog jezika”. Belaj i Tanacković Faletar (2010: 153) također razliku između imenskoga predikata u instrumentalu i nominativu svode na stilsku razliku. Katičić (2002: 46) i Raguž (2010: 146) ne navode nikakva ograničenja, no Raguž (2010: 146) navodi da je pojava instrumentala u imenskom predikatu rijetka i izrazito stilski obilježena. 
Je li instrumental uz kopulativni glagol biti samo stvar stila? Da bi se odgovorilo na to pitanje, potrebno je temeljito dijakronijsko i poredbeno istraživanje. No u ovom će se radu pokušati odgovoriti na to pitanje analizom korpusa hrvatskoga jezika te metodom ispitivanja jezične intuicije izvornih govornika. Pozornost nije usmjerena na književne i znanstvene tekstove (v. Rišner 2002), nego na novinske tekstove, komentare, blogove i slične vrste koje se mogu naći na Hrvatskom mrežnom korpusu (hrWac), zbog čega je odabran taj korpus.

Na velikom broju primjera iz Hrvatskoga mrežnoga korpusa (http://nl.ijs.si/noske/ all.cgi/first_form?corpname=hrwac;align=) pokušale su se uočiti pravilnosti u pojavi instrumentala povezane s glagolskim vremenom, značenjem imenica koje se javljaju u službi imenskoga predikata te drugim rečeničnim elementima.

\subsection{Ograničenje glagolskoga vremena}

Pretpostavka da je instrumental obilježen u prezentu potvrdila se i u ovom istraživanju, odnosno pronađen je malen broj potvrda (8-9).

(8) Svakodnevno sam svjedokom kako žene beskrupulozno nastoje osvojiti oženjene muškarce.

(9) I sama sam dijelom tog sustava...

Instrumental se javlja uz glagol biti u perfektu, a važno je istaknuti da se često javlja kada se u rečenici navodi vremenski okvir događaja, odnosno godina (10), razdoblje (1112), vremenski prilog (13). To se može povezati s pretpostavkom da se instrumentalom izražava privremenost stanja, odnosno da nije riječ o trajnoj identifikaciji (usp. Ivić 1954, Vince 2010: 255).

(10) Godine 2002. bio sam voditeljem skupa Filozofija i tehnika.

(11) Samo u zadnjih nekoliko mjeseci bio sam svjedokom različitih ozdravljenjâ...

(12) Tijekom rata, Vukovar je bio žrtvom neopisivog nasilja...

(13) ...predstava koja je lani bila sudionikom Državnog festivala kazališnih amatera Međimurja.

Predikatno ime u instrumentalu dolazi uz glagol biti u futuru i nisu uočene posebnosti u odnosu na perfekt (14-16).

(14) Po četvrti će puta Umag biti centrom glazbenih zbivanja u regiji...

(15) Dobra je fora i pokloniti joj biljku koja će biti simbolom vašeg prijateljstva...

(16) Dušan Ljuština za nju rekao da će ona biti ravnateljicom Kerempuha kad (i ako) on ikada ode u mirovinu.

Pitanje je zašto je instrumental obilježen uz glagol biti u prezentu. U okviru generativne sintakse Bailyn i Rubin (1991) i Bailyn (2001, 2012), polazeći od toga da predikat uvodi funkcionalna glava Pred koja kada nije glasovno ostvarena, ima jako pa- 
dežno obilježje instrumentala, objašnjavaju da u ruskom jeziku u prezentu nije moguća pojava instrumentala jer glavu Pred ispunjava morfološka nula koja apsorbira jako padežno obilježje zbog čega se nužno javlja nominativ. Rečenice s instrumentalom uz glagol biti u perfektu i futuru smatraju sekundarnim predikatima, odnosno izjednačuju ih s dopunama glagola smatrati, držati, činiti se i dr. Takvo su objašnjenje prihvatili mnogi jezikoslovci, uz poneke modifikacije. ${ }^{9}$ Prema tome u ruskom dopune kopule i semikopulativnih glagola projekcija su glave Pred koja zahtijeva instrumental. Za hrvatski se navodi da se uz glagol biti uopće ne javlja instrumental, odnosno glava Pred nema to obilježje, ali ima kada je riječ o semikopulativnim glagolima. Time bi se kopula i semikopulativni glagoli u hrvatskom razlikovali više nego u ruskom jeziku. Kao što smo vidjeli, ipak se uz glagol biti javlja instrumental, a također se javlja nominativ uz semikopulativne glagole, štoviše, često je neutralniji od instrumentala (npr. uz postati, ostati). Stoga Bailynov $(2001,2012)$ čisto sintaktički pristup temeljen na padežnim obilježjima funkcionalne kategorije nije prihvatljiv $\mathrm{u}$ analizi te pojave $\mathrm{u}$ hrvatskom jeziku.

U okviru kognitivne gramatike ograničenje da se instrumental ne javlja u prezentu može se objasniti načelom blizine (proximity principle) (Rakhilina i Tribushinina 2010) ili kognitivne udaljenosti prema čemu je konceptualna udaljenost povezana i s formalnom udaljenošću i što su dva entiteta bliža, i njihovo će obilježavanje biti bliže. Drugim riječima, pojava instrumentala moguća je u perfektu i futuru jer je veća udaljenost između subjekta i onoga što je on bio odnosno onoga što će tek postati, dok u prezentu nema te udaljenosti i zbog toga se i na sintaktičkoj razini ostvaruju istim padežom (usp. Belaj i Tanacković Faletar 2010: 165).

\subsection{Ograničenje semantičke skupine predikatne imenice}

Pretraživanjem korpusa uočava se da se kao predikatno ime u instrumentalu javlja ograničen broj imenica. Najčešće se javljaju imenice svjedok i dio.

Česte su imenice koje izražavaju:

1. kakvo zanimanje: sudac, profesor, plesač, trener, asistent i sl.

2. nosioca kakve čelne funkcije ili organizacije: predsjednik, ministar, prorektor, dekan, ravnatelj, direktor, upravitelj, voditelj, gradonačelnik i sl. ${ }^{10}$

3. osobu koja je dio čega: član, sudionik, dionik, potpisnik, pripadnik, pobornik i sl.

4. uzrok ili uzor čemu: razlog, uzrok, izvor, uzor, model, primjer, inspiracija, simbol i sl.

9 Primjerice, Matushansky (2000) i Markman (2008) u svojim istraživanjima stavljaju naglasak na pitanje zašto samo u prezentu nije moguća pojava instrumentala, dok u ostalim glagolskim oblicima jest jer je također glava Pred ispunjena kao i u prezentu. Osim toga i druge morfološke nule, odnosno glasovno neostvarene kategorije mogu provjeravati padež, primjerice $v$ u ruskom, a tako i u hrvatskom. Povezuju rečenice Nom-Inst s aspektom, točnije Matushansky (2000) smatra da glava AspP dodjeljuje instrumental, a Markman (2008) smatra da to čini predikatna glava koja je događajna (PredEv), odnosno koja uvodi prostorno-vremenski argument $e$.

10 Pojava imenica te skupine $\mathrm{u}$ instrumentalu mogla bi se objasniti analogijom prema glagolu upravljati te $s$ tim da je funkcija prolazna, tj. nije neodvojiva od nosioca. 
5. temu čega: predmet, tema, fokus, objekt, sadržaj, jezgra i sl.

6. temelj čega: osnova, podloga, temelj i sl.

7. cilj čega: cilj, meta i sl.

8. kakvo mjesto: mjesto, poprište, sjedište, prijestolnica i sl.

Teško je odrediti što je zajedničko svim tim imenicama, no čini se da i za hrvatski jezik vrijedi da se instrumentalom naglašava privremenost, odnosno da je riječ o stečenom svojstvu ili vremenski ograničenom stanju, dok se nominativom izražava trajno svojstvo, pa se tako u instrumentalu ne javljaju ili se javljaju iznimno rijetko imenice koje označuju rodbinske odnose, nacionalnost i druga inherentna svojstva. U rečenicama s predikatnim imenom u instrumentalu nije riječ o identifikaciji, odnosno o izjednačavanju s konkretnim pojedincem, nego o pripisivanju referenta kojoj kategoriji. Tako u okviru kognitivne gramatike Langacker (2008: 397) razlikuje rečenice s predikatnim imenicama koje se odnose na određenu individuu (Joyce is my cousin. 'Joyce je moj rođak.') i pripisivanje kategoriji kako bi se karakterizirao subjekt (Joyce is an actress. 'Joyce je glumica.'). Vince (2010: 255) smatra da predikatne imenice „ne izjednačuju subjekt s nekim određenim referentom, nego ga uključuju u skup imenovanih osoba, predmeta ili pojava", stoga imaju generičku ulogu. To je u skladu s ranije opisanim razlikovanjem predikatne i ekvivalentne rečenice, u kojoj se upućuje na određenu individuu, odnosno dolazi do identifikacije, te pojava instrumentala nije moguća.

Imenice se razlikuju s obzirom na stupanj obveznosti specifikacije. Imenice koje označuju zanimanje ne zahtijevaju specifikaciju te je riječ o pripisivanju pojedinca određenoj kategoriji (17), imenice koje označuju nosioca kakve čelne funkcije ili organizacije zahtijevaju specifikaciju, bilo posvojnim pridjevom ili imenicom u genitivu bilo da je poznato iz konteksta (18), a isto tako imenice drugih skupina nužno zahtijevaju specifikaciju da bi rečenica imala smisla (19).

(17) Ne zaboravimo da je Heinlen bio piscem.

(18) Gospodin Crnić bio je predsjednikom Ustavnog suda Republike Hrvatske...

(19) Unija je bila razlogom gubitka slobode.

Instrumental se može javiti u rečenicama u kojima se uz imenicu nalazi posvojna zamjenica (20) ili pridjev (21).

(20) ...ti koji si bio našim suputnikom i supatnikom.

(21) ...koji im je donedavno bio dobrim prijateljem.

Već je rečeno da se imenice koje izražavaju rodbinske odnose ne javljaju u instrumentalu jer su obično određene, tj. odnose se na određenoga referenta (v. Adger 2013: 60ff). Postoje iznimke, tako u primjeru (22) instrumentalom se želi naglasiti da to više nije njezina majka, odnosno osoba se potpuno promijenila, a slično se može zaključiti i za primjere (20-21). 
(22) Stojim pored toga što je nekad bilo mojom majkom i tresem se.

Iz navedenih primjera čini se da je upotreba instrumentala moguća kada je riječ o stečenom ili prolaznom svojstvu, što se može povezati i s time da se instrumental ne javlja, odnosno javlja se iznimno rijetko u prezentu.

\subsection{Ograničenje pridjeva}

U hrvatskom se jeziku u službi imenskoga predikata u perfektu (23) i futuru (24) javlja pridjev označen instrumentalom, no iznimno rijetko. To svojstvo hrvatski dijeli s poljskim jezikom.

(23) Gréco osvaja pariške pjesnike glasom prema kojem nitko nije bio ravnodušnim...

(24) ...te da napadi protiv Italije neće prestati „sve dok Iran neće biti sigurnim”...

To se može objasniti u skladu s tumačenjem Belaja i Tanackovića Faletara (2010) da se entiteti označeni imenicama lakše konceptualiziraju neovisno o drugim entitetima, dok se pridjevom označuju osobine nositelja i teško ih je konceptualizirati neovisno o nositelju. ${ }^{11}$

Objašnjenje da se instrumentalom označuje privremena atribucija djeluje prihvatljivo i ima podlogu s obzirom na to da se u instrumentalu javljaju imenice koje pripadaju određenoj semantičkoj skupini te se javljaju uz glagol u perfektu ili futuru, no pitanje je osjećaju li izvorni govornici tu razliku i koliko često upotrebljavaju instrumental u kopulativnim rečenicama.

\section{Ispitivanje jezične intuicije izvornih govornika hrvatskoga jezika}

U anketi koja je bila dana izvornim govornicima bez lingvističkoga obrazovanja ispitanicima je ponuđen tekst ${ }^{12} \mathrm{u}$ koji su trebali upisati imenice iz zagrade $\mathrm{u}$ odgovarajućem padežu. ${ }^{13} S$ kopulativnim glagolom biti dane su rečenice (27-28).

(27) Djed je nakon završetka škole bio (prodavač) u trgovini mješovite robe.

11 Uz glagol bivati uočava se da je često pridjev obilježen instrumentalom, i to uz komparativ i često uz usporednu česticu sve, bez obzira na glagolsko vrijeme (25-26).

(25) Ta vreva bivaše sve življom.

(26) Na koncu, ljudi bi s godinama trebali ipak bivati zrelijima...

Tomu je tako jer je u tim primjerima glagol bivati istoznačan glagolu postajati uz koji je upotreba instrumentala češća i neobilježena.

12 Anketa je provedena u okviru istraživanja za doktorski rad (v. Brač 2017). Anketa je napravljena u Google docs obrascu te je u ispitivanju sudjelovalo 106 ispitanika. Osim upotrebe instrumentala uz glagol biti provjeravala se upotreba uz semikopulativne glagole, no u ovom su radu izdvojena pitanja koje se odnose na glagol biti.

13 Dio ispitanika nije shvatio zadatak. Primjerice, u vezi s rečenicom (27) 1,90\% ispitanika odgovorilo je „radio kao prodavač” i 0,95\% „prodavao”. 
(28) Jednom prilikom bio je (svjedok) pljačke trgovine i uspješno je oborio provalnika.

U vezi s primjerom (27) čak $96,23 \%$ ispitanika upotrijebilo je nominativ, a tek 0,94\% instrumental. Zanimljivo je da je 67,92\% ispitanika u primjeru (28) napisalo svjedok, a čak $31,13 \%$ svjedokom. S obzirom na to da je utvrđeno da se imenica svjedok najčešće javlja u instrumentalu, moguće je da su upotrijebili instrumental jer se češće susreću s tom imenicom u instrumentalu nego s imenicom prodavač, odnosno djeluje im manje strano. Može se objasniti i tako da je uloga svjedoka kraća od uloge prodavača.

Ispitanicima su bile dane i rečenice (29-30) u vezi s kojima su trebali napisati postoji li značenjska razlika između njih i koja je.

(29) Profesor Horvat bio je dekan Pomorskoga fakulteta.

(30) Profesor Horvat bio je dekanom Pomorskoga fakulteta.

Među ispitanicama 55,66\% smatra da ne postoji razlika između primjera (29) i (30), dok je 32,08\% ispitanika navelo da je rečenica u primjeru (30) netočna, čudna ili neprirodna. Dio ispitanika (7,55\%) smatra da postoji razlika, no nisu naveli koja je, dok 2,83\% ispitanika uočava da je razlika u trajanju, odnosno rečenica (30) znači da je profesor Horvat bio dekan u određenom vremenskom okviru, a 0,94\% da je u rečenici (29) izraženo duže trajanje. „Svečaniji ton” u primjeru (30) uočilo je 0,94\% ispitanika.

(31) Umag će ponovno biti središte glazbenih zbivanja.

(32) Umag će ponovno biti središtem glazbenih zbivanja.

U vezi s primjerima (31) i (32) 61,32\% ispitanika smatra da nema razlike u značenju, a $26,42 \%$ ocijenilo je rečenicu (32) čudnom ili netočnom. Da postoji značenjska razlika, navelo je $8,49 \%$ ispitanika, no bez objašnjenja, dok je 1,89\% ispitanika navelo da primjer (31) označuje jednokratno trajanje, a (32) znači da će se u Umagu što događati duže vrijeme. Također $1,89 \%$ ispitanika smatra da je u primjeru (31) naglasak na Umagu, a u (32) na zbivanjima.

Može se zaključiti da ispitani govornici ne upotrebljavaju ili rijetko upotrebljavaju instrumental uz glagol biti u perfektu i futuru. Također, većina ispitanih govornika ne osjeća značenjsku razliku između primjera s predikatnim imenom u nominativu i u instrumentalu, a često rečenice $s$ instrumentalom ocjenjuju kao čudne i netočne. Time se jasno razlikuje od upotrebe u ruskom jeziku čiji izvorni govornici prepoznaju tu razliku.

\section{Zaključak}

U hrvatskom se jeziku u predikatnim kopulativnim rečenicama predikatno ime najčešće javlja u nominativu, a iznimno $u$ instrumentalu. Potvrđena su zapažanja hrvatskih jezikoslovaca da se rijetko javlja u prezentu, češće u perfektu i futuru. U 
okviru generativne gramatike ta se pojava u ruskom jeziku objašnjava tako da glavu Pred, koja ima inherentno obilježje instrumentala, ispunjava morfološka nula koja apsorbira to obilježje i ostavlja nominativ kao jedinu mogućnost, dok Bailyn $(2001,2012)$ navodi da hrvatski nema to obilježje. Budući da se u hrvatskom ipak može javiti instrumental, ta se pojava može objasniti time da se instrumental javlja uz glagol biti u perfektu i futuru jer nije riječ o trajnoj identifikaciji i izjednačavanju, nego o pripisivanju subjektu kakve uloge ili svojstva koje nije trajno povezano s njim i neodvojivo od njega. Tu pretpostavku potvrđuje i činjenica da se u instrumentalu rijetko javljaju pridjevi, što je značajka koju hrvatski dijeli s poljskim jezikom u kojem se NP javlja u instrumentalu, a AP u nominativu. Također se u instrumentalu najčešće javljaju imenice koje pripadaju određenim semantičkim skupinama, koje većinom zahtijevaju specifikaciju. Prema svemu navedenom može se zaključiti da je na hrvatski jezik primjenjiva pretpostavka uočena za ruski jezik i pojedine druge slavenske jezike da se instrumentalom izražava privremeno svojstvo, dok nominativom trajno. No i kada je riječ o privremenom svojstvu, svejedno se češće upotrebljava nominativ, dok je instrumental rubna pojava, kao što je rečeno.

Pretpostavku o postojanju značenjske razlike između rečenica u kojima je predikatno ime označeno nominativom od onih u kojima je označeno instrumentalom opovrgavaju rezultati dobiveni ispitivanjem jezične intuicije izvornih govornika koji nisu prepoznali tu razliku. Trećina ispitanika rečenice $s$ instrumentalom ocijenila je čudnima i netočnima, što upućuje na to da se (danas) upotrebi instrumentala u tim konstrukcijama treba pristupiti kao stilu. Potrebno je dijakronijsko i poredbeno istraživanje kako bi se sa sigurnošću utvrdilo kada se i u kojim konstrukcijama počeo upotrebljavati instrumental u hrvatskom i drugim južnoslavenskim jezicima u kojima je njegova upotreba rijetka.

Zašto baš instrumental alternira s nominativom može se objasniti analogijom $\mathrm{s}$ instrumentalom uz semikopulativne glagole, a vjerojatno i utjecajem ruskoga i drugih slavenskih jezika, no to bi trebalo dodatno proučiti.

\section{Literatura}

Adger, David (2013) A Syntax of Substance, The MIT Press, Cambridge - London.

Babukić, Vjekoslav (1854) Ilirska slovnica, pretisak Instituta za hrvatski jezik i jezikoslovlje 2014.

Bailyn, John F. (1991) „The Configurationality of Case Assignment in Russian”, Cornell Working Papers in Linguistics 9, 57-98.

Bailyn, John F. (2001) „The Syntax of Slavic Predicate Case”, ZAS Papers in Linguistics 22, 1-23.

Bailyn, John F. (2012) The Syntax of Russian, Cambridge University Press, New York.

Bailyn, John F., Edward J. Rubin (1991) „The Unification of Instrumental Case Assignment in Russian", Cornell Working Papers in Linguistics 9, 99-126. 
Barić, Eugenija i dr. (1997) Hrvatska gramatika, Školska knjiga, Zagreb.

Belaj, Branimir, Goran Tanacković Faletar (2010) „Konceptualnosemantički temelji gramatičkih odnosa: predikatni instrumental u hrvatskom jeziku", Suvremena lingvistika 70, 147-172.

Belaj, Branimir, Goran Tanacković Faletar (2014) Kognitivna gramatika hrvatskoga jezika. Imenska sintagma i sintaksa padeža, Disput, Zagreb.

Belaj, Branimir, Goran Tanacković Faletar (2017) Kognitivna gramatika hrvatskoga jezika. Sintaksa jednostavne rečenice, Disput, Zagreb.

Birtić, Matea (2001) „Imati ili biti”, Riječ 7, 2, 7-14.

Brač, Ivana (2017) Sintaktička i semantička analiza besprijedložnoga instrumentala u hrvatskom jeziku, doktorska disertacija, Filozofski fakultet Sveučilišta u Zagrebu.

Damjanović, Stjepan (2005) Staroslavenski jezik, Hrvatska sveučilišna naklada, Zagreb.

Della Bella, Ardelio (1728) Istruzioni grammaticali della lingua illirica, pretisak Instituta za hrvatski jezik i jezikoslovlje 2006.

den Dikken, Marcel (2006) Relators and Linkers. The Syntax of Predication, Predicate Inversion, and Copulas, The MIT Press, Cambridge.

Geist, Ljudmila (2006) „Copular Sentences in Russian vs Spanish at the SyntaxSemantics Interface”, ZAS Papers in linguistics 44, 99-110.

Heggie, Lorie A. (1988) The syntax of copular structures, doktorska disertacija, University of Southern California.

Heycock, Caroline (2012) „Specification, equation and agreement in copular sentences”, Canadian Journal of Linguistics 52, 2, 209-240.

Heycock, Caroline, Anthony Kroch (1999) „Pseudocleft connectedness: Implications for the LF Interface Level", Linguistic Inquiry, 30, 3, 365-397.

Higgins, Roger F. (1973) The pseudo-cleft construction in English, doktorska disertacija, Massachusetts Institute of Technology.

Huntley, David (1993) „Old Church Slavonic”, The Slavonic Languages, ur. Bernard Comrie i Greville G. Corbett, Routledge, London - New York, 125-187.

Ivić, Milka (1954) Значењ а српскохрватског инструментала и њихов развој, Srpska akademija nauka, Beograd.

Jahić, Dževad, Senahid Halilović, Ismail Palić (2004) Gramatika bosanskoga jezika za srednje škole, Dom štampe, Zenica.

Jakobson, Roman (1936) Beitrag zur allgemeinen Kasuslehre Gesamtbedeutungen der russischen Kasus. Etudes dédiées au Quatrième Congrès de Linguistes. Prag, 240288. [Prevedeno na engleski i ponovno izdano 1984. u Roman Jakobson: Russian and Slavic Grammar. Studies 1931-1981, ur. Linda R. Waugh i Morris Halle, Mouton Publishers, Berlin - New York - Amsterdam, 59-104].

Janda, Laura A., Steven J. Clancy (2002) The Case Book for Russian, Slavica, Bloomington. 
Kašić, Bartol (1604) Osnove ilirskoga jezika u dvije knjige, pretisak Instituta za hrvatski jezik i jezikoslovlje 2002.

Katičić, Radoslav (2002) Sintaksa hrvatskoga književnog jezika, Nakladni zavod Globus i Hrvatska akademija znanosti i umjetnosti, Zagreb.

Kučanda, Dubravko (1998) Rečenični subjekt u hrvatskom i engleskom jeziku, doktorska disertacija, Filozofski fakultet Sveučilišta u Zagrebu.

Langacker, Ronald W. (2008) Cognitive Grammar: A Basic Introduction, Oxford University Press, New York.

Markman, Vita G. (2008) „The Case of Predicates (Revisited): Predicate Instrumental in Russian and Its Restrictions", Journal of Slavic Linguistics 16, 2, 187-246.

Marković, Ivan (2009) „Rezultativni sekundarni predikat u hrvatskome”, Suvremena lingvistika 68, 221-246.

Matushansky Ora (2000) „The instrument of inversion: Instrumental case and verb raising in the Russian copula", Proceedings of the 19th West Coast Conference on Formal Linguistics WCCFL 19, ur. Roger Billerey i Brook D. Lillehaugen, Cascadilla Press, Somerville, 101-115, prema Markman 2008.

Mikkelsen, Line (2005) Copular Clauses: Specification, predication and equation, John Benjamins Publishing Company, Amsterdam - Philadelphia.

Moro, Andrea (1997) The Raising of Predicates. Predicative Noun Phrases and the Theory of Clause, Cambridge University Press, Cambridge.

Mrázek, Roman (1964) Синтаксис русского творительного. (Структурносравнительное исследование, Státni pedagogicke nakladatelstvi, Prag.

Partee, Barbara (1986) „Ambiguous Pseudoclefts with Unambiguous Be”, Proceedings of the Sixteenth Annual Meeting of the North Eastern Linguistic Society, ur. Stephen Berman, Jae-Woong Choe i Joyce McDonough, MA: GLSA, Amherst, 354-366.

Pereltsvaig, Asya (2007) Copular Sentences in Russian. A Theory of Intra-Clausal Relations, Springer, Dordrecht.

Piper, Predrag i dr. (2005) Синтакса савременога српског језика: проста реченииа, Institut za srpski jezik SANU, Beogradska knjiga i Matica srpska, Beograd.

Potebnja, Aleksandr Afans'evič (1888/1954) Из записок по русской грамматике, Akademija nauk SSSR, Moskva. Dostupno na: http://elib.gnpbu.ru/text/ potebnya_iz-zapisok-po-russkoy-grammatike_t1-2_1958/go,2;fs,1/, pristupljeno 10. siječnja 2016.

Priestly, Tom M. S. (1993) „Slovene”. The Slavonic Languages, ur. Bernard Comrie i Greville G. Corbett, Routledge, London - New York, 388-454.

Radford, Andrew (2004) Minimalist Syntax. Exploring the Structure of English, Cambridge University Press, Cambridge.

Raguž, Dragutin (2010) Gramatika hrvatskoga jezika, Vlastito izdanje, Zagreb. 
Rakhilina, Ekaterina, Elena Tribushinina (2010) „The Russian instrumental-ofcomparasion: constructional approach", Slavic Linguistics in a Cognitive Framework, ur. Marcin Grygiel i Laura A. Janda, Peter Lang, Frankfurt am Main, 145-174.

Rapaport, Tova Rebecca (1987) Copular, nominal, and small clauses: a study of Israeli Hebrew, doktorska disertacija, Massachusetts Institute of Technology.

Ribarova, Zdenka, Slavomira Ribarova (2015) Češka gramatika, Porfirogenet, Zagreb.

Rišner, Vlasta (2002) „O stilskoj izražajnosti predikatnoga imena u instrumentalu”, Jezik 49, 10-18.

Rothstein, Susan (2001) Predicates and their Subjects, Kluwer, Dordrecht.

Shevelov, George Y. (1993) „Ukrainian”, The Slavonic Languages, ur. Bernard Comrie i Greville G. Corbett, Routledge, London - New York, 947-998.

Short, David (1993a) „Czech”, The Slavonic Languages, ur. Bernard Comrie i Greville G. Corbett, Routledge, London - New York, 455-532.

Short, David (1993b) „Slovak”, The Slavonic Languages, ur. Bernard Comrie i Greville G. Corbett, Routledge, London - New York, 533-592.

Short, David (1993c) „Sorbian”, The Slavonic Languages, ur. Bernard Comrie i Greville G. Corbett, Routledge, London - New York, 593-685.

Silić, Josip, Ivo Pranjković (2005) Gramatika hrvatskoga jezika za gimnazije i visoka učilišta, Školska knjiga, Zagreb.

Stowell, Tim (1978). „What was there before there was there?”, Papers from the fourteenth regional meeting of the Chicago Linguistic Society, ur. Donka Farkas, Wesley M. Jacobsen i Karol W. Todrys, Chicago, Chicago Linguistic Society, 458-471, prema Mikkelsen 2005.

Stowell, Tim (1989) „Subject, specifiers and X-Bar Theory”, Alternative Conceptions of Phrase Structure, ur. Mark R. Baltin i Anthony S. Kroch, The University of Chicago Press, Chicago, 232-262, prema Pereltsvaig 2007.

Swan, Oscar E. (2002) A Grammar of Contemporary Polish, Slavica, Bloomington.

Timberlake, Alan (2004) A Reference Grammar of Russian, Cambridge University Press, Cambridge.

Vince, Jasna (2010) „Nominativ prema ostalim padežima”, Sintaksa padeža, ur. Matea Birtić i Dunja Brozović Rončević, Institut za hrvatski jezik i jezikoslovlje, Zagreb, 249-265.

Weber, Adolfo (1859) Skladnja ilirskoga jezika, za niže gimnazije, pretisak Instituta za hrvatski jezik i jezikoslovlje 2005.

Wierzbicka, Anna (1980) The case for surface case, Karoma, Ann Arbor.

Williams, Edwin (1983) „Semantic vs. syntactic categories”, Linguistics \& Philosophy 6, 423-446.

Zovko Dinković, Irena (2011) „Egzistencijalni glagoli u hrvatskome”, Suvremena lingvistika 72, 279-294. 


\section{SUMMARY \\ Ivana Brač \\ THE INSTRUMENTAL CASE IN COPULAR SENTENCES}

This paper analyses the structure of copular sentences and problematizes their division into predicational, specificational, equative and identificational sentences.

Our emphasis is on predicate copular sentences in which the post-copular NP can appear in the nominative or the instrumental case in Croatian, just like in some other Slavic languages. Occurrences of the instrumental case in copular predicates are extremely rare in south Slavic languages and there is some question as to when they appear at all. This paper presents the different theories about the occurrence of the instrumental case in predicative nominals (Mrázek 1964, Bailyn and Rubin 1991). Bailyn and Rubin (1991) consider the use of the instrumental case in secondary predicate adjuncts in the Russian language to be a language innovation, while Croatian and many other Slavic languages have a pattern that is found in the Old Church Slavonic and Old Russian languages. The paper also analyses Croatian grammars, written before the $20^{\text {th }}$ century, with the goal of determining when the instrumental case first appeared with the copula. Many linguists (e.g. Jakobson 1936, Mrázek 1964, Wierzbicka 1980, Janda and Clancy 2002, Timberlake 2004, Geist 2006, Pereltsvaig 2007) consider that the copular sentences with the nominative or the instrumental case have different meanings in the Russian language: the nominative denotes a permanent, inalienable property of the subject, while the instrumental denotes a temporary property. This assumption is analysed in the Croatian language based on the examples from the relevant Croatian language corpora.

We confirm the constraint, described in Croatian grammars, that the instrumental cannot appear with the copula in the present tense, but is possible in the perfect and future tenses. Cognitive grammar explains this by the application of the proximity principle: conceptual distance is related to formal distance. Therefore, the instrumental can appear with the copula in the perfect and future tenses, because there is distance between the subject and what he/she/it has been, or is going to become. Conversely, in the present tense there is no distance, and therefore the precopular and post-copular NPs have the same case.

It is noted that nouns belonging to specific semantic groups appear in the instrumental case (profession, function, part of something, reason for something, goal, base etc.).

We conclude that the instrumental case denotes temporary, acquired properties, while the nominative case denotes permanent, inalienable properties. This conclusion is drawn using examples from the relevant Croatian language corpora and based on the fact that the instrumental cannot appear with present tense and that adjectives are rarely marked with instrumental. Furthermore, these conclusions were tested by examining native speakers' linguistic intuition. Native speakers did not recognize the semantic difference between sentences with a nominative predicate NP and an AP and instrumental. Therefore, our conclusion is that the instrumental case is related to style.

Key words: copula be; copular sentence; instrumental; nominative; Croatian language; Russian language 